\title{
Cohalogenation of Limonene, Carvomenthene and Related Unsaturated Monoterpenic Alcohols
}

\author{
Antonio M. Sanseverino, Flavia M. da Silva, Joel Jones Jr* and Marcio C. S. de Mattos* \\ Departamento de Química Orgânica, Instituto de Química, Universidade Federal do Rio de Janeiro, \\ CP 68545, 21945-970, Rio de Janeiro - RJ, Brazil
}

\begin{abstract}
A coalogenação de $(R)$-limoneno e $(R)$-carvomenteno com $\mathrm{I}_{2} / \mathrm{H}_{2} \mathrm{O} / \mathrm{Cu}(\mathrm{OAc})_{2} \cdot \mathrm{H}_{2} \mathrm{O}$ em dioxano aquoso seguida por tratamento em meio básico produz estereoespecificamente os transepóxidos correspondentes. Já essa mesma metodologia de coalogenação aplicada a álcoois monoterpênicos insaturados estruturalmente relacionados produz derivados do pinol [a partir de $(5 R)$-cis-carveol e $(S)$ - $\alpha$-terpineol] ou então iodoidrinas [a partir de $(S)$-álcool perílico e $(5 R)$ trans-carveol].
\end{abstract}

Cohalogenation of $(R)$-limonene and $(R)$-carvomenthene with $\mathrm{I}_{2} / \mathrm{H}_{2} \mathrm{O} / \mathrm{Cu}(\mathrm{OAc})_{2} \cdot \mathrm{H}_{2} \mathrm{O}$ in aqueous dioxane followed by base treatment produced stereospecifically the corresponding trans-epoxides. Same methodology of cohalogenation applied to related monoterpenic unsaturated alcohols produced pinol derivatives [from $(5 R)$-cis-carveol and $(S)$ - $\alpha$-terpineol] or iodohydrins [from $(S)$ perillyl alcohol and $(5 R)$-trans-carveol].

Keywords: cyclisation, halohydrins, terpenes and terpenoids, electrophilic addition reaction

\section{Introduction}

Electrophilic halogenation of alkenes to produce vicinal dihaloalkanes is a well-known reaction in organic chemistry ${ }^{1}$. A proposed mechanism for it goes through a $\pi$ complex among alkene and halogen, followed by decomposition to a bridged halonium ion intermediate and then a nucleophilic opening by the halide ion ${ }^{2}$. However, when the halogenation of the alkene is carried out in a nucleophilic solvent (water, alcohols, carboxylic acids, nitriles, etc), a competition between the halide ion and the solvent for opening of the halonium ion can occur and difunctionalized products are obtained ${ }^{2}$. This process, termed 'cohalogenation', proved to be useful for diverse synthetic applications $^{2,3}$ (Scheme 1).

Recently, we published an efficient coiodination of simple alkenes with oxygenated nucleophiles promoted by $\mathrm{Cu}(\mathrm{OAc})_{2} \cdot \mathrm{H}_{2} \mathrm{O}$ and other metal salts ${ }^{4}$ or by 2 mol equiv. of iodine in place of the metal salt ${ }^{5}$. Thus, using this simple methodology, iodohydrins $s^{4,6}$ and $\beta$-iodoethers ${ }^{5}$ were effectively prepared in good yields and high purity when the iodination of alkenes was performed in water or alcohols, respectively.

Dedicated to our teacher and mentor W. Bruce Kover, who taught us to find the beauty of each reaction.

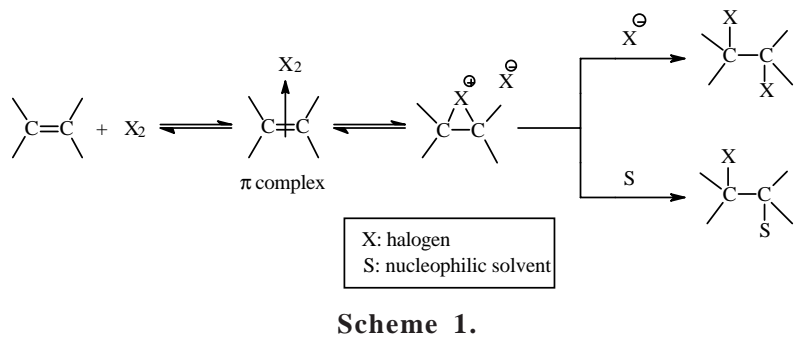

The role of the metal salt or of the second equivalent of iodine in the coiodination reactions is to decompose the $\pi$ complex formed among alkene and iodine to the bridged iodonium ion ${ }^{5,7}$. In the case of $\mathrm{Cu}(\mathrm{OAc})_{2}$, cupric iodide is formed followed by disproportionation to cuprous iodide and iodine ${ }^{7}$ (Scheme 2). As iodine is formed from $\mathrm{CuI}_{2}$, less than $1 \mathrm{~mol}$ equiv. of it is required for these reactions. On the other hand, in the absence of the metal salt (or without excess iodine), low conversion and poor yields of products are observed ${ }^{4,7}$.

Herein we communicate our results on the cohalogenation of limonene, carvomenthene and related unsaturated monoterpenic alcohols, namely carveols, $\alpha$-terpineol, and perillyl alcohol ${ }^{8}$.

\section{Results and Discussion}

The reaction of $(R)$-limonene $(\mathbf{1})$ with iodine in aque- 


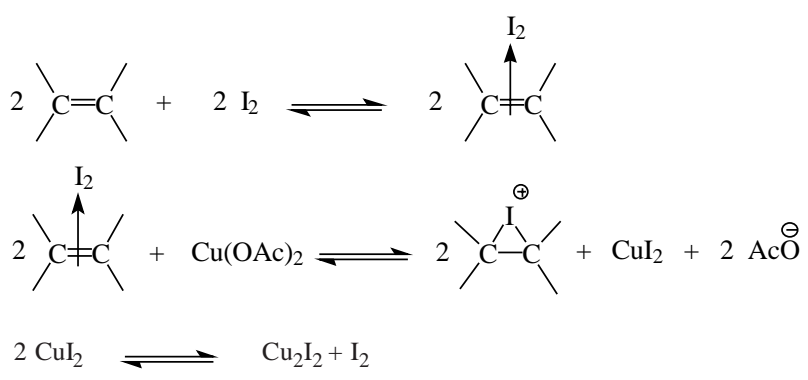

Scheme 2.

ous dioxane in the presence of $\mathrm{Cu}(\mathrm{OAc})_{2} \cdot \mathrm{H}_{2} \mathrm{O}$ was carried out at room temperature (rt) stirring together $1 \mathrm{~mol}$ equiv. of $1,0.5 \mathrm{~mol}$ equiv. of $\mathrm{Cu}(\mathrm{II})$ salt and addition of $0.75 \mathrm{~mol}$ equiv. of iodine. After $\mathrm{NaBH}_{4}$ reduction of the remaining excess of iodine and work up, HRGC (high-resolution gas chromatography) analysis of the crude material showed the unstable iodohydrin $2(82 \%)$ along with recovered substrate $(c a .15 \%)$. Several attempts to purify 2 were unsuccessful and only dark products and intense gas evolution were obtained. Treatment of $\mathbf{2}$ with $\mathrm{Na}_{2} \mathrm{CO}_{3}$ in aqueous ethanol produced pure trans-1,2-epoxylimonene $\mathrm{e}^{9,10}$ (3) in $59 \%$ isolated yield.

Catalytic hydrogenation of $(R)$-limonene to $(R)$-carvomenthene (4) and similar cohalogenation led to the iodohydrin 5 in $86 \%$ crude yield (ca. $8 \%$ recovered substrate). Base treatment of $\mathbf{5}$ produced trans-epoxycarvomenthene ${ }^{11}$ (6) in $59 \%$ yield. Scheme 3 summarizes all results.

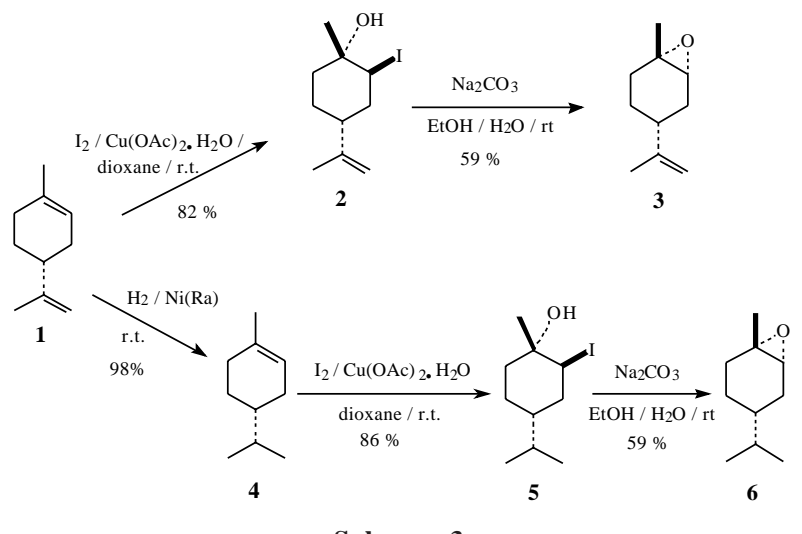

Scheme 3.

The characterization of $\mathbf{3}$ and $\mathbf{6}$ were made by comparison of their spectral data with those previously reported ${ }^{10,11}$ and by the ${ }^{13} \mathrm{C}$ NMR values of chemical shift for the $\gamma$-carbon of the epoxides and the parent alkenes, assuming that there is no significant difference if the epoxide ring is trans to the $\gamma$-carbon hydrogen ${ }^{12}$ (see Figure 1 ).

The results on the cohalogenation of limonene are important because electrophilic additions to it lack stereo

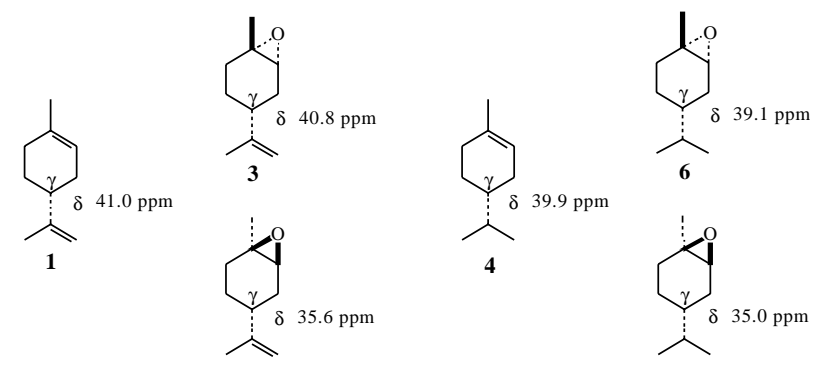

Figure 1. ${ }^{13} \mathrm{C}$ NMR chemical shifts (in $\mathrm{CDCl}_{3}$, relative to TMS) of $\gamma$-carbon for limonene, carvomenthene and related 1,2-epoxides.

and chemoselectivity ${ }^{13}$. The trans-epoxides were obtained stereospecifically and usual oxidation (peracids and related oxidants) of limonene and carvomenthene produced both a 1:1 mixture of cis- and trans-epoxides ${ }^{14}$, useful intermediates in synthesis of natural products ${ }^{15}$. Although the separation of both cis- and trans-1,2epoxylimonene can be achieved by careful spinning-band distillation ${ }^{16}$, this is a difficult and slow task and more practical methods of obtaining the pure trans-epoxide involve selective chemical transformation of the $1: 1 \mathrm{mix}-$ ture of isomers ${ }^{10}$ or reaction of limonene with $\mathrm{NBS} / \mathrm{H}_{2} \mathrm{O}$ followed by base treatment ${ }^{17}$. Moreover, trans-1,2epoxylimonene is more reactive than cis and so it is selectively opened on nucleophilic additions to the mixture of cis- and trans-1,2-epoxylimonene ${ }^{18}$.

A proposed mechanistic scheme (Scheme 4) for the stereospecific formation of the iodohydrin $\mathbf{2}$ derived from limonene (and the analogue $\mathbf{5}$ from carvomenthene) assumes a $\pi$ complex anti to the isopropenyl (or isopropyl) group, followed by its decomposition to the iodonium ion and an antiperiplanar opening by an axial ${ }^{19}$ nucleophilic attack of water on the tertiary carbon to produce the transdiaxial iodohydrin. Stereospecific formation of epoxides by base promoted cyclisation of halohydrins is vastly described in the literature 20

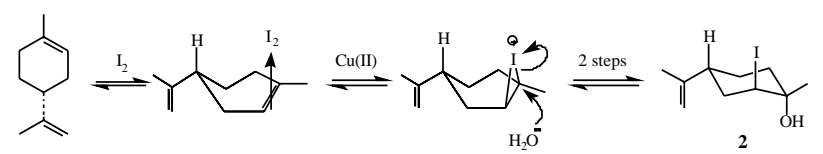

Scheme 4.

The above results led us to investigate the extension of this methodology of cohalogenation with unsaturated monoterpenic alcohols, as a possible route of cyclofunctionalization ${ }^{21}$ to produce functionalized bicyclic ethers.

The reaction of (5R)-carveols 7 (1:1 mixture of cis $7 \mathbf{a}$ and trans $\mathbf{7 b}$ isomers by $\mathrm{HRGC}$ ) with $\mathrm{I}_{2} / \mathrm{H}_{2} \mathrm{O} / \mathrm{Cu}(\mathrm{OAc})_{2} \cdot \mathrm{H}_{2} \mathrm{O}$ for 
$5 \mathrm{~h}$ led to an iodopinol derivative $(\mathbf{8})^{22}$ and an iodohydrin $(\mathbf{9})^{23}$, as shown in Scheme 5.

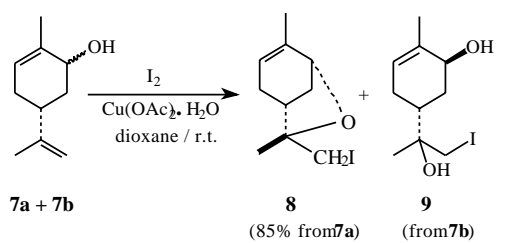

Scheme 5 .

Control experiments showed that cis-carveol (7a) was completely converted to $\mathbf{8}$ (85\% isolated yield based on 7a) in $1 \mathrm{~h}$ while $\mathbf{7 b}$ was unchangeable. After that, transisomer (7b) was slowly and incompletely converted to the iodohydrin 9 among other unidentified products. The structure of 8 was determined by ${ }^{1} \mathrm{H}$ and ${ }^{13} \mathrm{C}$ NMR 1D and 2D NMR techniques 24 (COSY, HMQC, and HMBC) and its relative stereochemistry was established with the aid of NOESY experiment that showed the cross signals shown in Figure $2^{25}$.

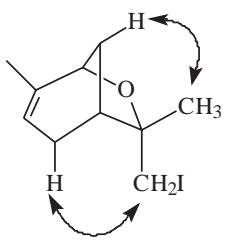

Figure 2. Essential NOE observed in NOESY spectra for determination of relative stereochemistry of $\mathbf{8}$.

These results contrast with those obtained for limonene and carvomenthene, where the reaction occurred at the trisubstituted double bond. In the case of carveols, probably due to electronic reasons, the allylic hydroxyl group deactivates the trisubstituted double bond to an electrophilic attack ${ }^{26}$ and the $\pi$ complex of $I_{2}$ is formed with the disubstituted double bond. Furthermore, the relative position of the hydroxyl is crucial to the nature of the products. When the hydroxyl is cis to the isopropenyl group (as in ciscarveol 7a) it can open the iodonium ion producing the iodo-bicyclic ether $\mathbf{8}$. On the other hand, if the hydroxyl is trans to isopropenyl (trans-carveol 7b), this intramolecular process is less favorable and water in the media slowly opens the iodonium ion producing the iodohydrin 9 (Scheme 6).

The reaction of $(S)$ - $\alpha$-terpineol (10) with iodine and water in the presence of cupric acetate led predominantly to trans-4-hydroxy-dihydropinol (11) ${ }^{27}$ along with some unidentified minor products. From the reaction mixture, 11 was isolated in $45 \%$ yield after radial chromatography (Scheme 7).

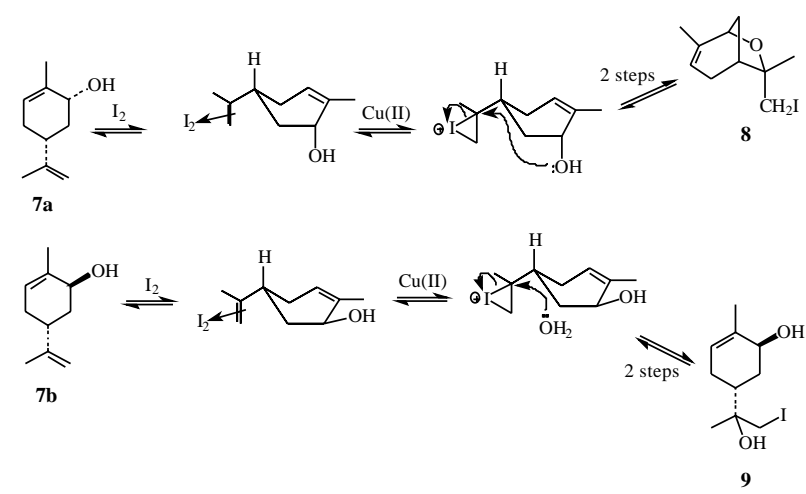

Scheme 6.

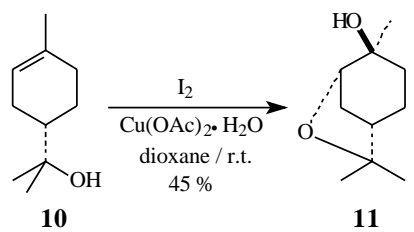

Scheme 7.

The structure of $\mathbf{1 1}$ was determined by ${ }^{1} \mathrm{H}$ NMR (that showed a sharp signal of a tertiary hydroxyl group upon changing the solvent from $\mathrm{CDCl}_{3}$ to DMSO- $\mathrm{d}_{6}$ ) along with ${ }^{1} \mathrm{H}$ and ${ }^{13} \mathrm{C}$ NMR $1 \mathrm{D}$ and $2 \mathrm{D}$ techniques ${ }^{24}$, assuming the most stable conformation being a bridged chair form $^{28}$. NOESY experiment showed the cross signals shown in Figure $3^{25}$.

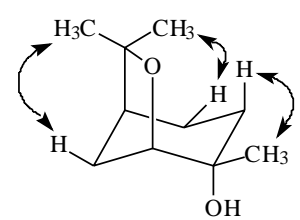

Figure 3. Essential NOE observed in NOESY spectra for determination of relative stereochemistry of $\mathbf{1 1}$.

The formation of the dihydropinol derivative $\mathbf{1 1}$ by the cohalogenation methodology is an attractive alternative to the thallium(III)-induced cyclization of $\alpha$-terpineol ${ }^{29}$.

A proposed mechanistic scheme (Scheme 8) for the rationalization of the hydroxy-dihydropinol $\mathbf{1 1}$ could be the formation of an iodonium ion (similar in the case of limonene and carvomenthene) followed by intramolecular opening to the unstable $\beta$-iodoether intermediate 12 (detected by MS in the reaction media ${ }^{30}$ ). This kind of intermediate easily rearranges through a bridged oxonium ion (13) to dihydropinol derivatives ${ }^{31}$. Regiospecific opening of the oxonium ion by $\mathrm{H}_{2} \mathrm{O}$ produced $\mathbf{1 1}$ in two further steps. 

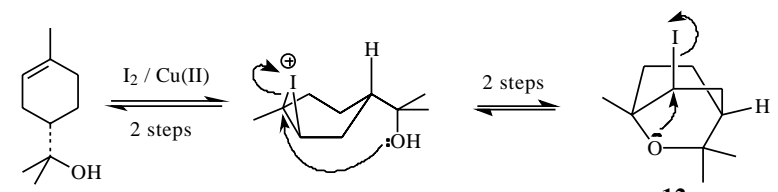

12

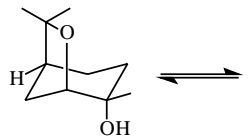

11

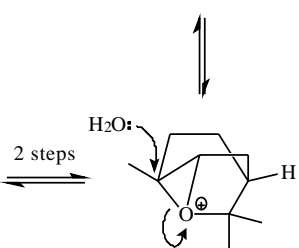

13
Scheme 8 .

Reaction of $(S)$-perillyl alcohol (14) with $\mathrm{I}_{2} / \mathrm{H}_{2} \mathrm{O}$ / $\mathrm{Cu}(\mathrm{OAc})_{2} \cdot \mathrm{H}_{2} \mathrm{O}$ was not completed after several hours and produced the diastereomeric iodohydrins $\mathbf{1 5}$ predominantly along with diiodohydrin ${ }^{32} \mathbf{1 6}$ ( $c$ a $18: 1$ by HRGC) and several others minor products (epoxides, iodo-triols, etc) Scheme 9. From this reaction mixture, 15 (a diastereomeric mixture) was isolated in $15 \%$ yield after radial chromatography. Once more, no bicyclic products were formed because it would be necessary a bridgehead unsaturated sevenmembered cyclic transition state. Attempts to improve the yield of 15, lower the subproducts or increase the consumption of perillyl alcohol were unsuccessful. No significative changes in the crude reaction mixture were observed in HRGC analysis when the cohalogenation was performed with 2 mol equiv. $\mathrm{I}_{2}$ in the place of cupric acetate ${ }^{5}$.

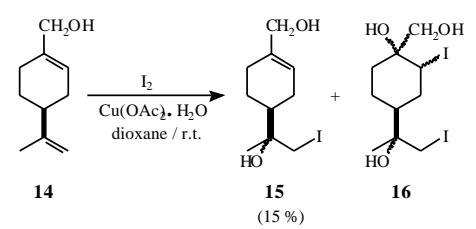

Scheme 9.

In summary, cohalogenation of limonene and carvomenthene with $\mathrm{I}_{2} / \mathrm{Cu}(\mathrm{OAc})_{2} \cdot \mathrm{H}_{2} \mathrm{O}$ in aqueous dioxane produce stereospecifically iodohydrins which upon base treatment are converted to the respective epoxides. On the other hand, when the cohalogenation is applied to related unsaturated monoterpenic alcohols, the nature of products is highly dependent on the structure of substrates. Thus, iodohydrins and bicyclic ethers are produced from interor intramolecular reactions, respectively.

\section{Experimental}

$(R)$-Limonene $\left\{[\alpha]_{D}^{28}+118.7\right.$ (neat) $\}$ and $(S)$ - $\alpha$-terpineol $\left\{[\alpha]_{D}^{28}-76.0\left(\mathrm{c} 1.0, \mathrm{CHCl}_{3}\right)\right\}$ were purchased from Dierberger,
(5R)-carveols $\left\{[\alpha]_{D}^{28}-108.1\right.$ (c 1.1, $\left.\mathrm{CHCl}_{3}\right)$, ca. 1:1 mixture of cis- and trans-isomers $\}$ and $(S)$-perillyl alcool $\left\{[\alpha]_{D}^{28}-\right.$ $\left.91.0\left(\mathrm{c} 1.0, \mathrm{CHCl}_{3}\right)\right\}$ were purchased from Aldrich.

$(R)$-Carvomenthene $\left\{[\alpha]_{D}^{28}+78.5\left(\mathrm{c} 2.0, \mathrm{CHCl}_{3}\right)\right\}$ was prepared in $98 \%$ yield (> $99 \%$ purity) by catalytic hydrogenation of $(R)$-limonene, as described by Jackman et al. ${ }^{33}$

Infrared (IR) spectra were recorded on a Perkin Elmer 1600 series FTIR (film in $\mathrm{NaCl}$ pellets). Analyses by HRGC were performed on a HP-5890-II gas chromatograph with FID by using a RTX-5 silica capillary column and $\mathrm{H}_{2}$ (flowrate $50 \mathrm{~cm} / \mathrm{s}$ ) as carrier gas. Mass spectra (MS) were obtained on a Hewlett-Packard HP 5896-A (column: SE54) or on a Hewlett-Packard HP 5937 (column: OV-1) HRGC-MS spectrometers using electron impact $(70 \mathrm{eV})$. ${ }^{1} \mathrm{H}(300 \mathrm{MHz})$ and ${ }^{13} \mathrm{C}(75 \mathrm{MHz})$ NMR spectra were acquired on a Bruker spectrometer for $\mathrm{CDCl}_{3}$ solutions with TMS as internal standard. Polarimetric analyses were performed on a Jasco DIP 370 polarimeter.

\section{(1S,2S,4R)-2-Iodo-4-isopropenyl-1-methylcyclohexanol (2)}

To a stirred solution of $(R)$-limonene $(1.36 \mathrm{~g}, 10.00 \mathrm{mmol})$ and $\mathrm{Cu}(\mathrm{OAc})_{2} \cdot \mathrm{H}_{2} \mathrm{O}(1.00 \mathrm{~g}, 5.00 \mathrm{mmol})$ in dioxane $(22 \mathrm{ml})$ and water $(3 \mathrm{ml})$, was added $\mathrm{I}_{2}(1.90 \mathrm{~g}, 7.50 \mathrm{mmol})$ in small lots at rt. After $4 \mathrm{~h}, \mathrm{Cu}_{2} \mathrm{I}_{2}$ was filtered off and $\mathrm{CHCl}_{3}(30 \mathrm{ml})$ was added to the filtrate. The resulting solution was treated with a suspension of $\mathrm{NaBH}_{4}(1 \mathrm{~g})$ in $\mathrm{EtOH}(50 \mathrm{ml})$ and then washed with water $(3 \times 20 \mathrm{ml})$. The organic layer was dried $\left(\mathrm{Na}_{2} \mathrm{SO}_{4}\right)$ and filtered through a small silica gel column. The solvent was evaporated in a rotatory evaporator at reduced pressure and low heating to produce crude 2 (2.30 g, $8.21 \mathrm{mmol}, 82 \%)$, along with recovered limonene (15\%). $[\alpha]_{D}^{28}+103.5\left(\mathrm{c} 2.0, \mathrm{CHCl}_{3}\right) \cdot{ }^{1} \mathrm{H} \mathrm{NMR}\left(\mathrm{CDCl}_{3}\right): \delta 1.00-2.00$ $(\mathrm{m}, 7 \mathrm{H}), 1.37$ (s, 3H), 1.44 (s, 3H), 2.85 (br s, 1H), 4.46 (d, 1H, J $8.5 \mathrm{~Hz}), 5.12$ (br s, 1H) ppm. ${ }^{13} \mathrm{C} \mathrm{NMR}\left(\mathrm{CDCl}_{3}\right): \delta 21.3$ $\left(\mathrm{CH}_{3}\right), 26.1\left(\mathrm{CH}_{2}\right), 30.5\left(\mathrm{CH}_{3}\right), 33.5\left(\mathrm{CH}_{2}\right), 37.4\left(\mathrm{CH}_{2}\right)$, $40.0(\mathrm{CH}), 43.1(\mathrm{CH}), 70.4(\mathrm{C}), 109.4\left(\mathrm{CH}_{2}\right), 148.2(\mathrm{C}) \mathrm{ppm}$. MS: m/z (\%): $280\left(\mathrm{M}^{+}, 1\right), 153$ (42), 135 (62), 107 (46), 93 (50), 71 (58), 43 (100).

\section{trans-1,2-Epoxy-(R)-limonene (3)}

The crude iodohydrin $2(2.30 \mathrm{~g}, 8.21 \mathrm{mmol})$ was treated with $\mathrm{Na}_{2} \mathrm{CO}_{3}(1.59 \mathrm{~g}, 15.00 \mathrm{mmol})$ in water $(40 \mathrm{ml})$ and ethanol $(10 \mathrm{ml})$. After stirring for $24 \mathrm{~h}$ at $\mathrm{rt}$ the reaction mixture was extracted with ether $(3 \times 10 \mathrm{ml})$ and the organic phase dried $\left(\mathrm{Na}_{2} \mathrm{SO}_{4}\right)$. The solvent was evaporated in a rotatory evaporator at reduced pressure and the residue purified by column chromatography $\left(\mathrm{SiO}_{2}\right.$, hexane, chloroform) to give epoxide $\mathbf{3}$ (0.74 g, $4.87 \mathrm{mmol}, 59 \%)$. $[\alpha]_{D}^{28}+78.0\left(\mathrm{c} 1.0, \mathrm{CHCl}_{3}\right)$. IR: $v_{\max } 3072,2960,2920,2860$, $1637,1437,1373,920,890,838 \mathrm{~cm}^{-1} .{ }^{1} \mathrm{H} \mathrm{NMR}\left(\mathrm{CDCl}_{3}\right)$ : 
$\delta 1.31-1.43(\mathrm{~m}, 2 \mathrm{H}), 1.34(\mathrm{~s}, 3 \mathrm{H}), 1.68(\mathrm{~s}, 3 \mathrm{H}), 1.65-1.77$ $(\mathrm{m}, 2 \mathrm{H}), 1.80-1.95(\mathrm{~m}, 1 \mathrm{H}), 2.00-2.10(\mathrm{~m}, 2 \mathrm{H}), 2.99(\mathrm{~d}, 1 \mathrm{H}$, J $5.38 \mathrm{~Hz}), 4.66$ (br s, $2 \mathrm{H})$ ppm. ${ }^{13} \mathrm{C} \mathrm{NMR}\left(\mathrm{CDCl}_{3}\right): \delta 18.1$ $\left(\mathrm{CH}_{3}\right), 20.2\left(\mathrm{CH}_{3}\right), 23.1\left(\mathrm{CH}_{2}\right), 30.0\left(\mathrm{CH}_{2}\right), 30.8\left(\mathrm{CH}_{2}\right)$, $40.8(\mathrm{CH}), 53.4(\mathrm{C}), 57.5(\mathrm{CH}), 109.1\left(\mathrm{CH}_{2}\right), 149.2(\mathrm{C})$

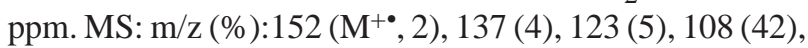
94 (62), 67 (62), 43 (100).

\section{(1S,2S,4R)-2-Iodo-4-isopropyl-1-methylcyclohexanol(5)}

$(R)$-Carvomenthene $(1.38 \mathrm{~g}, 10.00 \mathrm{mmol})$ used instead of $(R)$-limonene, other reagents and conditions being as described for 2 above. After all, it was obtained $2.43 \mathrm{~g}$ (8.62 mmol, $86 \%)$ of crude 5 , along with recovered carvomenthene $(8 \%)$. $[\alpha]_{D}^{28}+64.3\left(\mathrm{c} 2.0, \mathrm{CHCl}_{3}\right) \cdot{ }^{1} \mathrm{H}$ NMR $\left(\mathrm{CDCl}_{3}\right): \delta$ 0.90-2.02 (m, 8H), $1.37(\mathrm{~s}, 3 \mathrm{H}), 1.40(\mathrm{~s}, 3 \mathrm{H})$, 1.41 (s, 3H), 2.85 (br s, 1H), 4.40 (br s, 1H) ppm. ${ }^{13} \mathrm{C} \mathrm{NMR}$ $\left(\mathrm{CDCl}_{3}\right): \delta 20.1\left(\mathrm{CH}_{3}\right), 20.2\left(\mathrm{CH}_{3}\right), 24.6\left(\mathrm{CH}_{2}\right), 30.9\left(\mathrm{CH}_{3}\right)$, $31.6(\mathrm{CH}), 33.5\left(\mathrm{CH}_{2}\right), 36.5\left(\mathrm{CH}_{2}\right), 39.5(\mathrm{CH}), 43.1(\mathrm{CH})$, 71.5 (C) ppm. MS: m/z (\%): $267\left(\mathrm{M}^{+\bullet}\right.$ - Me, 2), 249 (2), 155 (75), 137 (80), 95 (71), 93 (50), 81 (90), 43 (100).

\section{trans-Epoxy-(R)-carvomenthene((6)}

The crude iodohydrin 5 ( $2.43 \mathrm{~g}, 8.62 \mathrm{mmol})$ was treated as described for 3 above to give epoxide $6(0.78 \mathrm{~g}, 5.06$ mmol, $59 \%) .[\alpha]_{D}^{28}+42.9\left(\mathrm{c} 1.0, \mathrm{CHCl}_{3}\right) \cdot{ }^{1} \mathrm{HNMR}\left(\mathrm{CDCl}_{3}\right)$ : $\delta 0.84(\mathrm{~d}, 6 \mathrm{H}), 1.30-1.34(\mathrm{~m}, 1 \mathrm{H}), 1.31$ (s, 3H), 1.37-1.40 $(\mathrm{m}, 2 \mathrm{H}), 1.53-1.62(\mathrm{~m}, 2 \mathrm{H}), 1.70(\mathrm{~m}, 2 \mathrm{H}), 1.98(\mathrm{~m}, 1 \mathrm{H}), 2.98$ $(\mathrm{d}, 1 \mathrm{H}, \mathrm{J} 5.37 \mathrm{~Hz}) \mathrm{ppm} .{ }^{13} \mathrm{C} \mathrm{NMR}\left(\mathrm{CDCl}_{3}\right): \delta 19.2\left(\mathrm{CH}_{3}\right)$, $19.5\left(\mathrm{CH}_{3}\right), 22.4\left(\mathrm{CH}_{3}\right), 23.0\left(\mathrm{CH}_{2}\right), 27.7\left(\mathrm{CH}_{2}\right), 30.8\left(\mathrm{CH}_{2}\right)$, $32.1(\mathrm{CH}), 39.1(\mathrm{CH}), 57.7(\mathrm{C}), 59.5(\mathrm{CH}) \mathrm{ppm} . \mathrm{MS}: \mathrm{m} / \mathrm{z}$ (\%): $154\left(\mathrm{M}^{+\bullet}, 5\right), 139(20), 125$ (12), 111 (50), 95 (10), 83 (20), 69 (40), 43 (100).

Typical procedure for the cohalogenation of unsaturated monoterpenic alcohols

To a stirred a solution of appropriated unsaturated monoterpenic alcohol $(5.00 \mathrm{mmol})$ and $\mathrm{Cu}(\mathrm{OAc})_{2} \cdot \mathrm{H}_{2} \mathrm{O}$ $(1.00 \mathrm{~g}, 5.00 \mathrm{mmol})$ in dioxane $(10 \mathrm{ml})$ and water $(2 \mathrm{ml})$, was added $\mathrm{I}_{2}(0.95 \mathrm{~g}, 3.75 \mathrm{mmol})$ in small portions at rt. After $16 \mathrm{~h}$ ( $1 \mathrm{~h}$ for carveols), the reaction media was filtered and $\mathrm{CHCl}_{3}(15 \mathrm{ml})$ was added to the filtrate. The resulting solution was washed with a saturated solution of $\mathrm{Na}_{2} \mathrm{SO}_{3}(3 \times$ $10 \mathrm{ml})$, the organic layer dried $\left(\mathrm{Na}_{2} \mathrm{SO}_{4}\right)$ and filtered through a small silica gel column. The solvent was removed under reduced pressure and low heating and the crude product purified by radial chromatography using $\mathrm{CH}_{2} \mathrm{Cl}_{2}$ as eluent.

(1R,5R,6S)-2,6-dimethyl-6-iodomethyl-7-oxabicyclo[3.2.1]-oct2-ene (8)

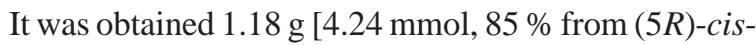
carveol]. $[\alpha]_{D}^{28}-17.8$ (c 1.0, $\left.\mathrm{CHCl}_{3}\right) .{ }^{1} \mathrm{H} \mathrm{NMR}\left(\mathrm{CDCl}_{3}\right)$ : $\delta 1.45$ (s, 3H), $1.72(\mathrm{~m}, 3 \mathrm{H}), 1.94(\mathrm{~d}, 1 \mathrm{H}, \mathrm{J} 10.74 \mathrm{~Hz}), 2.34$ (m, 3H), $2.52(\mathrm{~m}, 1 \mathrm{H}), 3.36(\mathrm{dd}, 2 \mathrm{H}, \mathrm{J} 22.61 \mathrm{~Hz}, 9.69 \mathrm{~Hz})$, 4.15 (d, 1H, J $4.41 \mathrm{~Hz}), 5.26(\mathrm{~m}, 1 \mathrm{H}) \mathrm{ppm} .{ }^{13} \mathrm{C} \mathrm{NMR}$ $\left(\mathrm{CDCl}_{3}\right): \delta 14.2\left(\mathrm{CH}_{2}\right), 17.9\left(\mathrm{CH}_{3}\right), 27.9\left(\mathrm{CH}_{3}\right), 29.7\left(\mathrm{CH}_{2}\right)$, $35.1\left(\mathrm{CH}_{2}\right), 40.7(\mathrm{CH}), 77.6(\mathrm{CH}), 84.1(\mathrm{C}), 120.7(\mathrm{CH})$, 139.8 (C) ppm.

(1S,2S,5S)-2,6,6-trimethyl-7-oxabicyclo[3.2.1]-octan-2-ol(11)

It was obtained $0.38 \mathrm{~g}(2.24 \mathrm{mmol}, 45 \%$ from $(S)-\alpha$ terpineol). $[\alpha]_{D}^{28}+25.6$ (c 10.0, $\left.\mathrm{CHCl}_{3}\right) .{ }^{1} \mathrm{H} \mathrm{NMR}\left(\mathrm{CDCl}_{3}\right)$ : $\delta 1.23(\mathrm{~s}, 3 \mathrm{H}), 1.24(\mathrm{~s}, 3 \mathrm{H}), 1,38(\mathrm{~s}, 3 \mathrm{H}), 1.43(\mathrm{~m}, 2 \mathrm{H}), 1.66$ (m, 2H), 1.84 (m, 2H), $2.17(\mathrm{~m}, 2 \mathrm{H}), 3.81$ (d, 1H, J $5.37 \mathrm{~Hz})$ ppm. ${ }^{1} \mathrm{H}$ NMR (DMSO-D 6 ): $\delta 1.13$ (s, 3H), 1.21 (s, 3H), 1.37 (s, 3H), $1.43(\mathrm{~m}, 1 \mathrm{H}), 1.74(\mathrm{~m}, 3 \mathrm{H}), 1.88(\mathrm{~m}, 1 \mathrm{H}), 2.05$ (m, 1H), 2.25 (d, 1H, J 11.55 Hz), 3.68 (d, 1H, J $6.33 \mathrm{~Hz}$ ), $4.45(\mathrm{~s}, 1 \mathrm{H}) \mathrm{ppm} .{ }^{13} \mathrm{C} \mathrm{NMR}\left(\mathrm{CDCl}_{3}\right): \delta 23.5\left(\mathrm{CH}_{3}\right), 24.3$ $\left(\mathrm{CH}_{2}\right), 28.7\left(\mathrm{CH}_{3}\right), 30.2\left(\mathrm{CH}_{3}\right), 31.9\left(\mathrm{CH}_{2}\right), 33.1\left(\mathrm{CH}_{2}\right)$, $41.3(\mathrm{CH}), 72.1(\mathrm{C}), 82.3(\mathrm{C}), 82.5(\mathrm{CH}) \mathrm{ppm}$. MS: m/z (\%) $170\left(\mathrm{M}^{+\bullet}, 5\right), 155(2), 137$ (1), 126 (23), 111 (10), 109 (16), 97 (18), 83 (10), 71 (45), 43 (100), 69 (27).

\section{(1'S, 2RS)-2-(4'-hydromethyl-3'-cyclohexenyl)-1-iodo-2-propanol(15)}

It was obtained $0.22 \mathrm{~g}$ [0.74 mmol, diastereoisomeric mixture, $15 \%$ from $(S)$-perillyl alcohol]. $[\alpha]_{D}^{28}-32.1$ (c 0.7, $\left.\mathrm{CHCl}_{3}\right)$. IR: $v_{\max } 3363,1674,1642,1191,1029 \mathrm{~cm}^{-1} .{ }^{1} \mathrm{H}$ NMR: $\delta 1.25$ (d, J 6.08 Hz), $1.82(\mathrm{~m}), 2.15(\mathrm{~m}), 3.45(\mathrm{~m})$, 4.05 (br s), $5.70(\mathrm{~m}) \mathrm{ppm} .{ }^{13} \mathrm{C}$ NMR: $\delta 21.70\left(\mathrm{CH}_{3}\right), 22.7$ $\left(\mathrm{CH}_{2}\right), 23.1\left(\mathrm{CH}_{2}\right), 23.3\left(\mathrm{CH}_{2}\right), 23.5\left(\mathrm{CH}_{3}\right), 24.1\left(\mathrm{CH}_{2}\right)$, $25.9\left(\mathrm{CH}_{2}\right), 26.3\left(\mathrm{CH}_{2}\right), 26.4\left(\mathrm{CH}_{2}\right), 26.6\left(\mathrm{CH}_{2}\right), 42.2(\mathrm{CH})$, 42.6 (CH), $66.9(\mathrm{CH} 2), 67.0(\mathrm{CH} 2), 72.1(\mathrm{C}), 72.2(\mathrm{C}), 121.5$ (CH), $122.2(\mathrm{CH}), 137.3(\mathrm{C}), 137.9(\mathrm{C}) \mathrm{ppm} . \mathrm{MS}: \mathrm{m} / \mathrm{z}(\%)$ $278\left(\mathrm{M}^{+\bullet}-\mathrm{H}_{2} \mathrm{O}, 4\right), 220$ (2), 185 (63), 169 (8), 151 (18), 133 (65), 93 (75), 79 (100), 43 (37).

\section{Acknowledgments}

We thank CNPq and PADCT for financial support of this work. AMS, FMS, and JJJ thank CNPq for fellowships. We also thank Carlos R. Kaiser, Rosane A.S. San Gil, and Cristiane P. S. Chaves for the NMR spectra and Claudia Moraes de Rezende for mass analyses.

\section{References}

1. De la Mare, P. B. D. Electrophilic Halogenation; Cambridge University Press; London, 1976.

2. Rodriguez, J. M.; Dulcère, J.-P. Synthesis 1993, 1177.

3. Spargo, P. L. Contemp. Org. Synth. 1995, 2, 85.

4. de Mattos, M. C. S.; Sanseverino, A. M. J. Chem. Res. (S) 1994, 440. 
5. Sanseverino, A. M.; de Mattos, M. C. S. Synthesis 1998, 1584.

6. Sanseverino, A. M.; de Mattos, M. C. S. Synth. Commun. 1998, 28, 559.

7. Georgoulis, C.; Valéry, J. -M. Bull. Soc. Chim. Fr. 1975, 2361.

8. Absolute configurations of substrates. (a) (R)-Limonene: Pawson, B. A.; Cheung, H. -C.; Gurbaxani, S.; Saucy, G. J. Chem. Soc. Chem. Commun. 1968, 1057. (b) (R)-Carvomenthene: Sakota, N.; Tanara, S. Bull. Chem. Soc. Jpn. 1971, 44, 485. (c) (5R)-Carveols: Buckingham, J. (Ed.) Dictionary of Organic Compounds, 5th ed., Chapman and Hall; New York, 1982. p. 3415. (d) (S)- $\alpha$-Terpineol: Fuller, A. T.; Kenyon, J. J. Chem. Soc. 1924, 125, 2304. (e) (S)-Perillyl alcohol: Büchi, G.; Hofhneinz, W.; Paukstelis, J. V. J. Am. Chem. Soc. 1969, 91, 6473.

9. The trans isomer refers to the isomer with 1,4-dialkyl groups trans to each other (Royals, E. E.; Leffingwell, J. C. J. Org. Chem. 1966, 31, 1937).

10. dos Santos, A. G.; Castro F. de L.; Jones Jr., J. Synth. Commun. 1996, 26, 2651.

11. Accrombessi, G.; Geneste, P.; Olivé, J. -L.; Pavia, A. A. Tetrahedron 1981, 37, 3135.

12. Pohlit, A. M.; Ferraz, H. M. C. Quím. Nova 1995, 18, 160.

13. de Mattos, M. C. S.; Kover, W. B. Quím. Nova 1991, 14, 91.

14. Leffingwell, J. C.; Royals, E. E. Tetrahedron Lett. 1965, 3829.

15. Ho, T. -L. Enatioselective Synthesis: Natural Products from Terpenes; John Wiley and Sons; New York, 1992, p 44, 45, 51.

16. Kergomard, A.; Veschambre, H. C. R. Hebd. Seances Acad. Sci. Ser. C 1974, 279, 155.
17. Gurudutt, K. M.; Rao, S.; Srinivas, P. Flavour Fragrance J. 1992, 7, 343.

18. Comins, D. L.; Guerra-Weltzien, L.; Salvador, J. M. Synlett 1994, 972.

19. Antonioletti, R.; D'Auria, M.; De Mico, A.; Piancatelli, G.; Scettri, A. Tetrahedron 1983, 39, 1765.

20. Berti, G. Top. Stereochem. 1973, 7, 93.

21. Cardillo, G.; Orena, M. Tetrahedron 1990, 46, 3321.

22. Yasui, K.; Fugami, K.; Tanaka, S.; Tamaru, Y. J. Org. Chem. 1995, 60, 1365.

23. MS: m/z (\%) $296\left(\mathrm{M}^{+\bullet}, 0.3\right), 278$ (0.7), 151 (50), 123 (50), 109 (90), 43 (100).

24. Croasmun, W. R.; Carlson, R. M. K. Two-Dimensional NMR Spectroscopy; VCR; New York, 1994.

25. Kaiser, C. R.; da Silva, F. M.; Jones Jr., J.; de Mattos, M. C. S. Spectrosc. Lett., submitted for publication.

26. Kahn, S. D.; Pau, C. F.; Chamberlin, A. R.; Hehre, W. J. J. Am. Chem. Soc. 1987, 109, 650.

27. Wolinsky, J.; Thorstenson, J. H.; Vogel, M. K. J. Org. Chem. 1977, 42, 253.

28. Carman, R. M.; Fletcher, M. T.; Lambert, L. K. Mag. Res. Chem. 1988, 26, 271.

29. Ferraz, H. M. C.; Ribeiro, C. M. R.; Grazini, M. V. A.; Brocksom, T. J.; Brocksom, U. Tetrahedron Lett. 1994, 35, 1497.

30. MS: m/z (\%) $280\left(\mathrm{M}^{+^{\bullet},}, 1\right), 265$ (5), 222 (2), 207 (1), 181 (1), 153 (41), 135 (19), 123 (1), 109 (10), 95 (100), 69 (14), 59 (57), 43 (59).

31. Carman, R. M.; Fletcher, M. T. Aust. J. Chem. 1983, $36,1483$.

32. MS: m/z (\%) $295\left(\mathrm{M}^{+\bullet}-\mathrm{H}_{2} \mathrm{O}-\mathrm{I}, 16\right), 281$ (25), 263 (8), 235 (16), 209 (6), 169 (24), 167 (100), 149 (34), 121(27), 93 (89), 79 (50), 43 (30).

33. Jackman, L. M.; Webb, R. L.; Yick, H. C. J. Org. Chem. 1982, 47, 1824. 